\title{
E por falar em magistério e educação ...
}

\author{
Elizabeth dos Santos Rios \\ Graduada em História Natural - Mestre em Ciências Biológicas (Botânica) \\ Atualmente é professora assistente da Universidade do Estado do Rio de Janeiro. \\ Tem experiência na área de Ecologia, com ênfase em Ecologia de \\ Ecossistemas, atuando principalmente em Ecologia, \\ Morfologia Vegetal, Educação Ambiental, Ensino de Biologia. \\ Atua também na Pós-Graduação do Curso de Especialização em Ensino de Ciências da UERJ, \\ lecionando a disciplina "Tópicos Especiais em Ensino de Ciências". \\ هelizabethrios@ig.com.br
}

Para entenderem a minha visão sobre vocação para o magistério, inicio com um breve histórico focando situações ocorridas em sala de aula, consideradas como "recursos" para melhorar o aproveitamento dos alunos, facilitando o processo de ensinoaprendizagem. Felizmente não fui aluna e nem professora em épocas tão remotas, onde qualquer atitude efetuada poderia ser considerada como abusiva, desrespeitosa, ou, até mesmo decorrente da falta de comportamento social. O estudante era submetido a um processo "corretivo", capaz de gerar modificações positivas em relação aos seus atos, segundo os conceitos da época. Tal método conhecido como "palmatória", também era aplicado quando não conseguiam responder corretamente às perguntas em sala de aula. 0 professor se apresentava como executor do processo. Será que alguém consegue adquirir conhecimentos através de agressão física?

Na década dos anos sessenta, surgiu o método do "castigo", onde o estudante por um deslize, geralmente de conduta, era colocado fora da sala de aula, permanecendo de pé em frente à porta. O "transgressor" das normas educacionais, como era considerado, ficava exposto às opiniões e críticas dos demais colegas. Servia como exemplo do que é oferecido a quem não tem bom comportamento. Não podemos esquecer que estes professores possivelmente já teriam passado pela etapa da palmatória, o que poderia justificar esta atitude, o que não deixa de ser um "processo evolutivo", visto que não existiam mais as tais agressões físicas. No entanto, surgiram as agressões morais.

Trazendo um acúmulo de frustrações, estes profissionais têm uma parcela de contribuição na formação dos novos discentes, onde muitos apresentam problemas notórios de timidez intensa, distúrbios de comunicação e expressão dos seus desejos profissionais e afetivos, tornando-se pessoas incapazes de se autodefenderem. Dizem "sim" em vez do "não" quando se sentem ameaçados em tomadas de decisões. Será que castigo ensina?

Com o avanço do tempo, me situo no século vinte e um. Inovações tecnológicas garantem informações rápidas e atualizadas com o uso do computador, dos telefones móveis e da mídia como um todo, que conquistam alunos e educadores. A utilização e importância destes recursos se fazem sentir no Ensino Fundamental, avançando pelo Ensino Médio até à 
Graduação, sendo considerados como ferramentas de trabalho no processo pedagógico e educacional. Esta conquista é relevante na construção do conhecimento e na relação de aproximação entre o professor e o discente.

Quando os alunos ingressam na Universidade, os professores se apresentam com outro perfil e conhecimento (Especialistas, Mestres e Doutores), na sua maioria exercendo atividades no ensino e na pesquisa. Devido às novas condições, alguns alunos se comportam de forma autoritária achando que sabem tudo, outros indecisos, esperando que façam tudo por eles, e, existem os que não se dedicam efetivamente ao estudo. Estes se graduam, sem explorar todo o seu potencial. Para atuar nesta realidade, é necessário que se tenha vocação para o magistério e que as atividades sejam efetuadas com ética e profissionalismo. Os alunos devem ser estimulados a liberdade de pensamento e expressão, para que possam ser ouvidas suas necessidades sem transgredirem as normas legais de conduta, tratamento e convivência com os seus semelhantes e demais seres vivos do planeta.

Mas o que falta? Na realidade o que pode estar faltando atualmente é a postura profissional do professor, assim como a conscientização individual e coletiva da classe de que você é o professor, educador e orientador que irá transmitir seus conhecimentos, atitudes, caráter e visual às pessoas, independente do local de trabalho e da quantidade de recursos disponíveis. Sem discriminações e preconceitos, se estabelece respeitosamente, o binômio "aluno-professor". Uma nova visão para a profissão é a interação do aluno com os diferentes meios de comunicação, o que já vem acontecendo através de atividades de pesquisa em sites educacionais, onde o professor apresenta os conceitos básicos, estimulando os alunos para que desenvolvam suas próprias conclusões sobre os fatos, seguida de uma discussão coletiva em sala de aula, junto com o professor. Se não podemos mudar conceitos, devemos estimular o raciocínio para que alcancem seus objetivos.

É gratificante que, além de professores, sejamos educadores e orientadores na construção do saber! 